\title{
Monopoly by Contract: The Practice of Franchised Fee and Royalty Rate
}

\author{
Maria Hamideh Ramjerdi
}

Montclair State University and William Paterson University, USA

\begin{abstract}
This paper uses a theoretical framework and a by use of a franchising model will examine the practice of charging a franchise fee for the use of the trademark and will show how this practice by controlling the number of franchised operations enables franchisor to extract monopoly profit. Paper will further examine the conditions which the joint practice of franchise fee and royalty rate allows extraction of monopoly rent.
\end{abstract}

Keywords: Monopoly, Franchising, Franchise Fee, Royalty Rate.

\section{INTRODUCTION}

A franchise is a contract between two agents, the franchisor and franchise. Franchisor sells the right to use a trademark, a finished product or service as well as methods and transfer of know how to the franchisee in exchange for a combination of fees such as territorial exclusivity, tied sales, royalty rate, franchise fee, quality controls, etc. This paper uses a homogeneous production function to examine the practice of charging a franchise fee for use of the trademark and shows how this practice by controlling the number of franchised operations raises the price of the franchised good and restricts output. And further examines the conditions which lead to extraction of monopoly rent when the joint practices of franchise fee and royalty rate are charged. Therefore, transfer of the consumer surplus to the franchisor's profit, hence creates deadweight loss to society. The paper is organized as follows: Section I defines franchise contract. Section II describes the types of franchising. Section III reviews franchising literatures. Section IV develops the model for the practice of franchise fee. Section $V$ examines the joint practice of franchise fee and royalty rate. And finally section VI summarizes the findings of this paper.

\section{FRANCHISING: ORIGIN OF THE NAME AND SOME EMPIRICAL EVIDENCE}

Franchising form of business arrangement originated from France in the 18th century. The term "franchising" in French, means "a granting of right" or "an exemption" Williamson, 1992). According to International Franchise Association (2013) "There were 828,138 franchised business establishments in the United States in 2007. Franchised businesses provided

*Address correspondence to this author at the Montclair State University and William Paterson University, USA; Tel: 973-258-9667;

E-mail: hramjerdi@veriszon.net
$9,125,700$ jobs, or 6.2 percent of the U.S. private nonfarm workforce in 2007. Franchised businesses supplied an annual payroll of $\$ 304.4$ billion, or 4.2 percent of all private nonfarm payrolls in the United States in 2007. Franchised businesses produced goods and services worth $\$ 802.2$ billion, or 3.4 percent of private nonfarm output in the United States in 2007. Franchised businesses contributed $\$ 468.5$ billion to GDP, or 3.9 percent of all private nonfarm GDP in the United States in 2007."

In the franchising literature a franchise system is defined as an economic organization in which the parent company "franchisor" has developed a method or a formula for producing, manufacturing, marketing and/or distributing a good or a service and grants the right "Franchise" to operate under the trade name to individuals or small companies subject to a number of controls and restrictions.

Ozanne and Hunt (1971) describe these controls or as franchisor name them, assistance as follows: hours of operation, standardized bookkeeping system, menu control, cleanliness standard, quality of product control, local advertising, control of retail price, and the number of employees. Thompson (1971) and Shane (2005) classify controls and restrictions in a broader term and add territorial and geographic areas of sale, the type of buyer the franchisor may deal with, managerial practices, training of employees, and standardize architectural appearances to the observations of Ozanne and Hunt.

Further restrictions imposed on franchisees are what constitute the expression of franchisors' motive of franchising, securing income, which is done by any combinations of the following practices:

1) Revenue-sharing, charging of a royalty-rate on the gross sale of the franchisees. 
2) Full-line forcing, the requirement of the purchase of inputs from either the franchisor or an approved supplier.

3) Payment of advertisement fee, contribution of a certain amount of money to the national advertising fund.

4) Franchise fee, payment of a fee at the time of the signing of the franchising contract.

\section{TYPES OF FRANCHISING}

Thomas H. Murphy (1970) in his report to US Select Subcommittee of Franchising divides franchise operations by industry into four distinct groups as follows:

1) Services such as employment agencies and rental agencies.

2) Product distribution which includes auto industry and brewing industry.

3) Fast foods.

4) Hotels and motels

Vaughn (1974), Thompson (1971), and Ozanne and Hunt (1971) group franchising operations according to the type of control imposed in the franchising agreement. The controls are representative of the nature and stage of production and manufacturerretailer system such as auto industries and their dealers and petroleum marketers and their dealers. The second type of franchise system is manufacturer wholesalers systems like soft drink and other bottlers, and syrup supplier's chains. The third type of franchise system is wholesaler-retailer, which includes hardware chains such as Goodyear and Firestone. Finally, the forth type of franchise system is trademark/trade namelicenser generally has a common trade name and standardized method for operation of retail units which market one or groups of products or one or groups of services or some combination of both under a common trade name with standardized architectural sites. Examples are motel chains, fast food restaurants, and auto and truck rental.

\section{THE MAIN REASONS FOR FRANCHISING}

There are substantial literatures on reasons a firm or an industry engages in the practice of franchising rather forward or backward integration into the market. The most widely used hypothesis is capital market theory of Oxenfelth and Kelly (1968-1969) which view the franchising phenomenon as follows: A franchisor has the idea but no capital, the franchisee supplies the capital and assumes a large part of the risk and in time the franchisor will obtain enough capital to start economies of scales and expand the industry. Thompson (1992) study supports capital constraints and indicates company with high rate of growth the number of franchised units is less likely to increase if units require a high level of capital. Sen's (1993) study suggests new franchisors charging a higher initial fee than older franchisors as firms in the early stages of growth need more resources, therefore supports capital market theory of franchising. However, according to Lafontaine and Kaufmann (1994) capital market theory fails to explain why firms who obviously have full access to capital markets franchise.

Rubin (1978) accepts the Oxenfeldt and Kelly and others' hypothesis is based on modern theory of capital only if the franchisors are more risk averse than franchisees, and since franchisee's investment constitute a large part of their assets, then franchisor risk and cost of capital can be reduced if franchisor invest in the entire system. Franchisors are often publicly-held companies whose owners hold diversified portfolios therefore the capital market theory of franchising is fallacious.

As a further explanation of the evolution of the franchised organization theories of risk sharing could be employed. In pure risk sharing models, franchisors and franchisee are assumed to be risk averse therefore a revenue sharing contract will benefit both franchisors and franchisee. Accordingly, a risk averse franchisor is more likely to add royalty payments in addition to fixed franchise fee in the contract. (Stiglitz, 1974 and Martin, 1988). Martin (1988) studied franchising from an industry perspective and found that the need to reach minimum efficient scale, capital prerequisites, market competition, and monitoring costs as reasons of franchising. Lafontaine (1992) found that franchising is a vehicle used by firms to grow faster. Thompson (1994) explores franchising based on scarcity of managerial ability and concludes that managerial ability is often a more scarce resource than capital for a growing organization. "As the firm grows, slack resources accumulate; thus scarcities of capital, managerial talent, and market knowledge diminish. Consequently, the firm may buy back franchising contracts."(Combs and Castrogiovanni, 1994: 38)

Coase divides transactions to within firms and between firms (1937). The sharp distinction between 
intra-firm and inter-firm transactions creates various optimal mixes of the intra-firm and inter-firm transactions. The franchise organization is one of these hybrid forms of business. Franchising enables industries that require highly decentralized operations at multiple sites to be competitive (Michael, 2000). Transactions between the franchisor and the franchisee are similar to market transaction between two independent firms. Unlike market transactions, under the formal franchise contract, the franchisor has most of the managerial controls over the franchisees decision makings. Therefore, the relationship between the franchisor and the franchisee is similar to an incomplete contract between a firm and an employee (Rubin, 1978).

Alchian and Demsetz (1972) elaborate on control and performance problems of operations when they are physically removed from the parent company. Thus it pays to devise the control mechanism and franchise the operations and avoid executive excessive consumption of leisure and inefficiency. Robin (1973) also explains franchising on efficiency grounds base on managerial functions which have large economies of scale such as advertising, and the franchisee will perform day-to-day managing of the operation which their costs due to control problems become large. Thus "the division of tasks between the franchisor and franchisee" is explained by average cost (economies of scale) of resuming the function. Rubin (1978) and Mathewson and Winter (1985) hold the scheme that managers (the agents) because their compensations are fixed, tend to shirk in their obligations to the firm (the principal) which results a high monitoring costs, to ensure managers (the agents) act in the firm's (the principal's) best interest. Hence, the contract between the principal (franchisor) and agent (franchisee) is intentioned to reduce the agency costs, franchiseeowned units are likely to be more profitable than company-owned units. Krueger (1991) observed that company-owned units generally seem to have lower profit margin $1.8 \%$ than franchise-owned units $9.5 \%$.

Certain contract clause such as royalty can reduce monitoring and control costs franchise operations minimizing transaction costs (Lafontaine 1992). Further support for the agency theory was provided by Dahlstrom and Nygaard (1994) assert that high rate of repeat customers per unit results in high employee monitoring costs, therefore makes franchising more favorable over company-owned units. Thomas, O'Hara, and Musgrave (1990), found that units with high sales are converted from franchised to company owned units due to spread monitoring costs over more sales dollars. Thompson (1992) also recounted that company ownership are in the areas where units tend to be large such as urban areas. Combs and Castrogiovanni (1994) established a significant support for riskspreading hypothesis and the agency theory but their study does not support capital market theory of franchising.

Shelton (1967) found that even though the managers of company- owned units received partly incentive payments franchised units outperformed company-owned units. Lillis, Narayana, and Gilman (1976) maintain the view that the high level of motivation of franchisees compared to paid employees is the most important advantage of franchising. Moreover, the presence of company-owned outlets serves as a credible threat of franchisee termination (Williamson 1996) because the franchisor "puts partners on notice ... if desired price and quality are not delivered" (Perryman and Combs, 2012: 374).

Another form of agency problem is franchisors' and franchisees' conflicting goals. Cox and Mason (2009) viewed franchising as geographical business model with conflicting goals, franchisor would like to maximize total franchised units revenue, and the franchisee prefers to maximize the revenue in its territory and the individual franchisee's. Kaufmann and Rangan (1990), mathematical model suggest a solution to these conflicting goals by integrating elements such as store choice and site location to optimize the counteracting effects of competition and attractiveness. Current and Storbeck (1994), analyzed conflicting objectives of franchisors and franchisees and develop a model of alternative site locations. Rent sharing is another explanation of franchising. Question arises as to how economic rents should be allotted to franchisee and the franchisor. The franchisors' sources of revenue are franchise fees, rental of sites, royalties, sale or leasing of equipment, sale of franchise products, sales of supplies raw materials and sale of territorial rights (Woll 1968-69). Bacus, Bacus, and Human (1993) found that franchise fees and royalty rates were determined according to industry, number of employees, age, type of services offered to franchisees, market share, and the franchisor's trademark value. Romano (1994) argues that franchisor can fully extract any economic rent through a franchise fee that is equal to the discounted present value of the expected franchisee's future profits. Sen (1993) established that tie-in sales, total per-unit capital, and percentage of units franchised determine the initial fees charged by a 
franchisor, although royalty rates are related to the level and range of services offered by the franchisor. Combs and Castrogiovanni (1994) found a positive correlation between the number of units franchised and the amount of royalty charged by the franchisor. The term "franchising" is sometimes used to refer to monopoly franchising, for example Zupan (1989), refers to the granting of exclusive rights by local authorities to the highest bidder as monopoly franchising, therefore creating monopoly profit. Inaba (1980) found that joint practice of royalty and tie-in sales enable franchisors to extract monopoly profit when the elasticity of demand remains constant, when elasticity of demand changes, since royalty rate is fixed at the time of contract only the practice of tie-in sales enables franchisors to extract monopoly profit.

\section{PRACTICE OF FRANCHISE FEE}

This paper investigates the practices of franchise fee and royalty rate, by assuming that the franchised operations are identical where each franchised operation produces the franchised good $y$ with the production function $y=f(x)$ where $\mathbf{x}=\left(x_{1}, \ldots \ldots \ldots ., x_{n}\right)$ is a vector of inputs which is bought at competitive price $r=\left(r_{1}, \ldots \ldots \ldots, r_{n}\right)$ vector on input prices. Constant return to scale characterizes the scale of operation (i.e. addition of one more unit of franchised operation would not change the cost of production). The franchised good faces the market demand $P=$ $P(Y)$ where $P^{\prime}<0$ and $Y=n y$

Given the above assumptions the franchisors best alternative is to operate as a multi-plant monopoly to extract monopoly profit. Following the rule of profit maximization the franchisor would equate the summation of marginal costs of the franchised operation equal to the marginal revenue and determine the price and the quantity of output produced.

$$
\begin{aligned}
& \Pi=P(Y) Y-n r x \\
& \Pi=P(n f(x)) n f(x)-n r x \\
& \nabla \Pi=P^{\prime}(n f(x) . n \nabla f(x) . n f(x)+n \nabla f(x) . P(n f(x)) \\
& -r n=0 \\
& r n=P^{\prime}(n f(x) . n \nabla f(x) . n f(x)+n \nabla f(x) . P(n f(x))
\end{aligned}
$$

By substituting (4) into (2) and rewriting $x \nabla f(x)$ as $f(x)$ by the constant return to scale assumption, the franchisor profit could be written as:

$$
\begin{aligned}
& \Pi=P\left(n f(x) . n f(x)-P^{\prime} n f(x) . n f(x) . n f(x)-n f(x) . P\right. \\
& (n f(x))
\end{aligned}
$$

or

$$
\Pi=-P^{\prime}\left(n f(x) .(n f(x))^{2}\right.
$$

Since $P^{\prime}<0$ the absolute value sign of the profit is positive. Dividing equation (6) by the number of plants $n$ which produces the monopoly output, will determine profit from each operation.

$$
\Pi / n=-P^{\prime}(n f(x)) n f(x)^{2}
$$

And dividing equation (7) by output of each franchised operation will result in the amount by which the monopoly pricing is greater than competitive pricing.

$$
\begin{aligned}
& \Pi / n / f(x)=-P^{\prime}(n f(x)) n f(x)=P m-P c \\
& P m-P c=-P^{\prime}(n f(x)) n f(x)
\end{aligned}
$$

Thus the monopolist profit maximizing condition implies both (10 and (11)

$$
\begin{aligned}
& P m-P c=-P^{\prime}(n f(x)) n f(x) \\
& \Pi=\left(P_{m}-P_{c}\right) y^{*}
\end{aligned}
$$

or

$$
P_{m}=P_{c}+\Pi / y^{*}
$$

The franchisor in order to extract monopoly profit would charge franchise fee equal to the monopoly profit. Therefore by setting the franchise fee $F$ for each operation equal to monopoly profit $\Pi / n$ and substitution of $n y^{*}=Y^{*}$ into (12) the following would result:

Hence

$$
\text { (15) } F=\left(P_{m}-P_{c}\right) y^{*}
$$

The franchisor in the absence of monopoly trade mark (i.e. free entry, would enter the market till price is equal to the average cost (by constant return to scale assumption). The intersection of this competitive price level and the market demand curve would determine the total output produced. Therefore the cost function $C$ $=c(y)$ for each franchisee can be formulated as follows:

The average cost function would be

$$
C / Y=c(y) / Y
$$


Each franchisee (firm) would charge a price $P(y)$ which is determined by the intersection of horizontal summation of average cost curves. Thus the competitive price that each firm is facing is:

$$
P_{c}(y)=c(Y) / Y=n(c(y) / n y) .
$$

When the industry for production of a good or service is franchised (i.e. the trademark is monopolized), the franchisor would charge the franchise fee $F(15)$. Each franchisee would take this fee as a part of the fixed cost of production and will enter the market until the price of the franchised good is equal to marginal cost. Thus each franchisee's cost function when the trademark is monopolized will be

$$
C=c(y)+F
$$

or

$$
C=c\left(y^{*}\right) P^{\prime}\left(n y^{*}\right) . n y^{*^{2}}
$$

And the average cost function would be

$$
C / y=c(y *) / y^{*}-P^{\prime}\left(n y^{*}\right) . n y^{*^{2} / y^{*}}
$$

or

$$
C / y=c\left(y^{*}\right) / y^{*}-P^{\prime}\left(n y^{*}\right) . n y^{*}=P\left(y^{*}\right)
$$

Theorem: By setting the optimum franchise fee the franchisor can force the same price and quantity that would obtain if were to monopolize the industry.

Proof: Since the franchise fee is fixed cost for the franchisee, then each franchisee would want to maximize:

$$
P y-P_{c} y-F=\left(P-P_{c}\right) y-F
$$

Where $P$ is a given market price (i.e. $P(n y)$ for the level of production $y$ ) and $P_{c}$ is the competitive price level. Since the summation of the franchise fee $F$ of all franchised operation is equal to monopoly profit. This implies that $\left(P-P_{c}\right) y-F \leq 0$ for any level of output $y$ of each franchisee. Since $P_{c}$ is equal to average cost of production (17), multiplying by output level $y$ will imply that total revenue and total cost, thus their difference is total profit. $F$ is the maximum level of profit (i.e. monopoly profit and is associated only with one level of output $y^{*}$ ) therefore at any level of output the difference between the associated profit and the maximum profit could only be zero or negative. Therefore each franchisee in order to maximize its profit must choose the level of output $y$ such that:
(23)

$$
P . y-P_{c} . y-F=0
$$

By substituting $F$ from (15)

$$
\left(P-P_{c}\right) \mathrm{y}-\left(P_{m}-P_{c}\right) y^{*}=0
$$

Since $P-P(n y)$ and $P^{\prime}<0$ there is one to one relationship between $P$ and $y$ as follows that $P=P_{m}$ and $y=y^{*}$

Therefore each franchisee to be at break-even-point (i.e. maximizing profit) would produce output $y^{*}$ with the market price $P_{m}$ which is exactly what the franchisor wants to extract monopoly profit.

The franchise fee as a tool to capture monopoly profit fails when the elasticity of market demand changes. The conditions for capturing monopoly profit are:

$P_{m}-P_{c}=-P^{\prime}\left(y^{*}\right) y^{*}$

Dividing both sides by $P_{m}$ will result

$$
P_{m}-P_{c} / P_{m}=-P^{\prime}\left(y^{*}\right) y^{*} / P_{m}=\varepsilon^{-1}
$$

$\Pi=\left(P_{m}-P_{c}\right) y^{*}=F$

Since $F$ is fixed at the time of the contract therefore any changes in the elasticity of demand of the franchised good would result to a new optimum $\mathrm{Pm}$ and $y^{*}$ and the associated optimum $F$.

To examine the effect of practice of charging a franchise fee on expansion path, the necessary condition of profit maximization implies

$$
\begin{aligned}
& r_{1} / r_{2}=\left[P\left(n f(x)+P^{\prime}(n f(x)) . n f(x)\right] f_{1} /[P(n f(x)+\right. \\
& \left.P^{\prime}(n f(x)) . n f(x)\right] f_{2}
\end{aligned}
$$

thus

(27) $r_{1} / r_{2}=f_{1} / f_{2}$

The vector of output price $P\left(P_{1}\right.$ $P_{n}$ ) could be determined by differentiation of total cost function (19) as follows:

$$
\begin{aligned}
& C=c(f(x))-P^{\prime}(n f(x)) n f(x)^{2} \\
& \left(\partial C / \partial x_{1}, \ldots \ldots \ldots . ., \partial C / \partial x_{n}\right)=C f(X) . \Delta f(x)-P^{\prime}(n f \\
& (x) n \nabla f(x)\left(n f(X)^{2}-2 n P^{\prime}(n f(x)) . n f(x) \nabla f(x)\right.
\end{aligned}
$$

$-P^{\prime}{ }^{\prime}(n f(x)=0$ by linearity of the demand curve, therefore:

$$
\begin{aligned}
& \left(\partial C / \partial x_{l}, \ldots \ldots \ldots \ldots, \partial C / \partial x_{n}\right)=\left[C^{\prime} f(X)-2 n P^{\prime}(n\right. \\
& f(x)) . n f(x)] \nabla f(x)
\end{aligned}
$$


or

$$
\begin{aligned}
& C_{1} / C_{2}=f_{1} / f_{2}=P_{1} / P_{2} \\
& P=\left[C f(X)-2 n P^{\prime}(n f(x)) . n f(x)\right] \nabla f(x)>[P(n f(x) \\
& +P^{\prime}(n f(x)] n \nabla f(x)=r
\end{aligned}
$$

$C^{\prime} f(x)$ is the competitive price $P^{\prime}(n f(x)) . n f(x)$ is the difference between monopoly and competitive pricing, $P(n f(x))$ is the monopoly price and taking the absolute sign into account (32) could be written as :

$$
\begin{aligned}
& P=\left[P_{c}+2 n\left(P_{m}-P_{c}\right)\right] \nabla f(x)>\left[P_{m}-P_{m}+P_{c}\right] \\
& \nabla f(x)=r
\end{aligned}
$$

Or the output price is proportional to input price

(32) $P=\lambda r$ for some positive $\lambda$.

Which implies that a relative change in input price will result to a relative change in output price, thus, the optimum franchised fee is intact. Furthermore the expansion path is not affected by the practice of franchise fee.

\section{JOINT PRACTICE OF FRANCHISE FEE AND ROYALTY RATE}

When both practice of franchise fee and royalty rate $\alpha$ are charged by franchisor the franchisor's profit could be written as follows:

$$
\begin{aligned}
& \text { (34) } \quad \Pi=\alpha P(n f(x)) n f(x)+n F \\
& \text { (35) } \quad F=(1-\alpha) P(n f(x)) f(x)-r x
\end{aligned}
$$

By substituting (35) into (34) implies that

$$
\Pi=P(n f(x)) n f(x)+n r x
$$

Upon maximization of (36) will result to full monopoly profit. Therefore the joint practice of franchise fee and royalty rate doesn't affect the potential of extraction of full monopoly profit by franchisor.

Extreme cases are when $\alpha=0$ by substituting into (34) and (35) implies that

$$
\begin{aligned}
& \text { (37) } \quad \Pi=n F \\
& \text { (38) } \quad F=P(n f(x)) f(x)-r x
\end{aligned}
$$

Substitution of (38) into (37) will result to:

$$
\Pi=P(n f(x)) n f(x)-n r x
$$

Which upon maximization of (39) implies the condition of (10) and (11) and by satisfying the condition will result of extraction full monopoly profit by franchisor.

Another extreme case is when $\alpha=\varepsilon^{-1}$ that is the optimum royalty rate which extract full monopoly profit by franchiser. Substitution of the condition of profit maximization of franchisee $[(1-\alpha) P(n f(x) . \nabla f) x)=r]$ and $\alpha=\varepsilon^{-1}$ the royalty rate that extract full monopoly profit into (35) and applying Euler's theorem will imply that:

$$
\begin{aligned}
& F=\left(1-\varepsilon^{-1}\right) P(n f(x)) f(x)-\left(1-\varepsilon^{-1}\right) P(n f(x)) \nabla f(x) \cdot x \\
& F=\left(1-\varepsilon^{-1}\right) P(n f(x)) f(x)-\left(1-\varepsilon^{-1}\right) P(n f(x)) \cdot f(x) \cdot x \leq \\
& O
\end{aligned}
$$

Which implies franchisee in order to operate they must at least be at their break-even-point, therefore, the franchise fee when the optimum royalty rate is charged is zero and substituting $F=0$ into (34) yields

$$
\text { (42) } \Pi=\alpha P(n f(x)) n f(x) \text { and } \alpha=\varepsilon^{-1}
$$

Dividing both sides by $\mathrm{n}$ and rearranging the terms yields input demand of each franchisee.

(43) $\quad r=\left[P(n f(x))+P^{\prime}(n f(x) \cdot n f(x)] \nabla f(x)\right.$

Under the practice of royalty rate the condition of profit maximization of franchisee requires that

$$
(1-\alpha) P(n f(x)) \nabla f(x)=r
$$

Where $\alpha$ is the royalty rate and when it is optimal (franchisor monopoly profit) is equal to $\varepsilon^{-1}$, the inverse of price elasticity of demand

(45) $\varepsilon^{-1}=-P^{\prime}(n f(x) \cdot n f(x) / P(n f(x))$

In order to compare the number of franchise licenses issued by franchisors the number of franchisees under the practice of franchise fee and royalty rate (since each operation is the same size) comparing the input demand of franchisees under the two practice would result in the comparison of the output of each franchisee operation, therefore the number of franchisees.

Under the practice of franchise fee the input demand of each franchised operation could be obtained from (4) the necessary condition for profit maximization 


$$
r n=P^{\prime}(n f(x) . n \nabla f(x) . n f(x)+n \nabla f(x) . P(n f(x)
$$

By substituting (45) into (44) will result

$$
\left[P\left(n f(x)+P^{\prime}(n f(x)) \cdot n f(x)\right] \nabla f(x)=r\right.
$$

(47) is exactly the same as (43) thus the number of franchisee under the practice of franchise fee and royalty rate are equal.

\section{CONCLUSION}

This study presents a mathematical model of monopoly franchising and proves that controlling the number of franchised unit enables the franchisor to extract full monopoly profit and transfer of the consumer surplus to the franchisor's profit. This paper further examined the joint practice of franchised fee and royalty rate as a tool for extraction of monopoly rent. Under the joint practice of the royalty rate and franchise fee the optimal royalty rate $\alpha=\varepsilon^{-1}$ the inverse of price elasticity of demand. When $\alpha=0$ franchise fee extracts the full monopoly profit, but in practice franchisor charges both franchise fee and royalty rate. In addition the optimal numbers of franchised units under both practices are equal. Since both franchise fee and royalty rate are constant at the time of the contract any change in elasticity of demand will result to a new optimum royalty rate and franchised fee which enables franchisor to extract monopoly profit, this could be an explanation as to why the franchise fee and royalty rates changes over time and differs across franchised industries. According to Lafontaine the average rate of sales-based royalties in the US was $6.5 \%$ in 1986 . This average rate is the largest in the auto service sector $(9.2 \%)$, is about $6 \%$ in the retailing sector, and is $6.6 \%$ in the restaurant sector (1992). Furthermore it could be argued that since there is an optimum number of franchised units which enable franchisor to extract monopoly profit as a motive for owned operated units and repurchasing franchised units. Combs and Castrogiovanni, 1994: 38) showed that repurchase "provide the firm with additional control, and by repurchasing the largest and most profitable franchises first, the firm captures additional rents previously allocated to the franchisee."

\section{ACKNOWLEDGEMENTS}

I am indebted to Dr. Fredrick S. Inaba, emeritus professor at Washington State University for interesting me on the topic and his valuable comments and suggestions on the mathematical model of this paper. I like to also thank an anonymous referee for productive suggestions, remaining errors are mine.

\section{REFERENCES}

Alchian, A.A. and Demsetz, H. 1972. "Production, information costs, and economic organization", American Economic Review, Vol. 62, Pp. 777-95. http://www.aeaweb.org/aer/index.php

Bacus, D.A., M.S. Bacus, and S.E. Human.1993. "Choosing a Franchise: How Base Fees And Royalties Relate to the Value of the Franchise," Journal of Small Business Management 31(3), Pp.91-104. http://onlinelibrary.wiley.com/ journal/10.1111/(ISSN) 1540-627X

Carney, M., and E. Gedajlovic. 1991). "Theoretical Integration in Franchise Systems: Agency Theory and Resource Explanations," Strategic Management Journal 12, Pp.607629. http://smj.strategicmanagement.net/ http://dx.doi.org/10.1002/smj.4250120804

Castrogiovanni, GJ., R.T. Justis, and S.D. Julian. 1993. "Franchise Failure Rates: An Assessment of Magnitude and Influencing Factors," Journal of Small Business Management (April), Pp.105-114. http://onlinelibrary.wiley.com/journal/10.1111/ (ISSN) 1540-627X

Caves, R., and W. Murphy.1976. "Franchising: Firms, Markets and Intangible Assets,"' Southern Economic Journal 42, Pp.572586. http://ideas.repec.org/s/sej/ancoec.html http://dx.doi.org/10.2307/1056250

Coase, R. 1937. "The nature of the firm", Economica, Vol. 4, Pp. 386-405. http://onlinelibrary.wiley.com/journal/10.1111/ (ISSN) 1468-0335

http://dx.doi.org/10.1111/j.1468-0335.1937.tb00002.x

Combs, J.G., and GJ. Castrogiovanni. 1994. "Franchisor Strategy: A Proposed Model and Empirical Test of Franchise versus Company Ownership," Journal of Small Business Management 32(2), Pp.37-48. http://onlinelibrary.wiley.com/ journal/10.1111/(ISSN) 1540-627X

Cox, Juliet and Colin Mason. 2009. "Franchise network restructuring: Pressures, constraints and mechanisms" Entrepreneurship \& Regional Development Vol. 21, Nos. 5-6, SeptemberNovember 2009, 503-527 http://www.ingentaconnect.com/ content/routledg/tepn

http://dx.doi.org/10.1080/08985620802365178

Cronin, J.J. and Taylor, S.A. 1992. "Measuring the quality of services: a reexamination and extension", Journal of Marketing, Vol. 56, Pp. 55-68. http://www.amaorders.com/ productdetail.aspx?id=jminstus http://dx.doi.org/10.2307/1252296

Current, J.R., and J.E. Storbeck. 1994. "A Multiobjective Approach to Design Franchise Outlet Networks," Journal of the Operational Research Society 45(1), Pp. 71-81. http://www.palgrave-journals.com/jors/index.html

Dahlstrom, R. and A. Nygaard. 1994. "A Preliminary Investigation of Franchised Oil Distribution in Norway," Journal of Retailing 70(2), Pp.179-191. http://www.journals.elsevier.com/journalof-retailing/

http://dx.doi.org/10.1016/0022-4359(94)90014-0

Hunt, S.D. 1973. "The Trend Toward Company-Operated Units in Franchise Chains," Journal of Retailing 49(2), Pp.3-12. http://www.journals.elsevier.com/journal-of-retailing/

Hunt, S.D., and J.R. Nevi. 1974. "Power in a Channel of Distribution: Sources and Consequences," Journal of Marketing Research $\mathrm{XI}$, Pp.186-193. http://www.amaorders.com/catalog.aspx? catid=JournalMarketingResearch http://dx.doi.org/10.2307/3150557

Inaba, Frederick S. 1980. "Franchising: Monopoly by Contract" Southern Economic Journal (April), Pp. 65-72. http://ideas. repec.org/s/sej/ancoec.html http://dx.doi.org/10.2307/1057061

International Franchise Association. 2013. "Franchising," retrieved from http://buildingopportunity.franchise.org/

Kaufmann, PJ. and V.K. Rangan. 1990. "A Model for Managing System Conflict during Franchise Expansion," Journal of 
Retailing 66(2), Pp.155-173. http://www.journals.elsevier. com/journal-of-retailing/

Krueger, A.B. 1991. "Ownership, Agency, and Wages: An Examination of Franchising in the Fast Food Industry," Quarterly Journal of Economics 106, Pp.75-101. http://ideas. repec.org/s/tpr/qjecon.html http://dx.doi.org/10.2307/2937907

Lafontaine, F. 1992. "Agency Theory and Franchising: Some Empirical Results," Rand Journal of Economics 23(2), Pp. 263-283. http://www.rje.org/ http://dx.doi.org/10.2307/2555988

Lafontaine, F., and PJ. Kaufmann. 1994. "The Evolution of Ownership Patterns in Franchise Systems," Journal of Retailing 70(2), Pp.97-113. http://www.journals.elsevier.com/ journal-of-retailing/ http://dx.doi.org/10.1016/0022-4359(94)90010-8

Lillis, C.M., C.L. Narayana, and J.L. Gilman. 1976. "Competitive Advantage Variation over the Life Cycle of a Franchise," Journal of Marketing, Pp.77-80. http://www.marketingpower. com/AboutAMA/Pages/AMA\%20Publications/AMA\%20Journ als/Journal\%20of\%20Marketing/JournalofMarketing.aspx http://dx.doi.org/10.2307/1251071

Markland, R.K., and R.W. Furst. 1974. "A Conceptual Model for Analyzing Discrete Alternative Franchising Portfolios: Design and Validation," Operational Research Quarterly 25, Pp. 267281. http://www.palgrave-journals.com/jors/free_articles.html

Martin, R. 1988. "Franchising and Risk Management," American Economic Review 78(5), Pp. 954-968. http://www.aeaweb. org/aer/index.php

Mathewson, G., and R. Winter. 1985. "The Economics of Franchise Contracts," Journal of Law and Political Economics 28, Pp.503-26. http://ideas.repec.org/s/ucp/jlawec.html http://dx.doi.org/10.1086/467099

Michael, S.C. 2000. "The effect of organizational form on quality: the case of franchising", Journal of Economic Behavior and Organization, Vol. 43 No. 3, pp. 295-318. http://www.journals. elsevier.com/journal-of-economic-behavior-and-organization/ http://dx.doi.org/10.1016/S0167-2681(00)00125-6

Murphy T.H. 1970. "The Impact of Franchising on Small Business Part I" US Government Printing Office Washington (1970), P. 204

Oxenfelt, A.R., and A.O. Kelly. 1968-69. "Will Successful Systems Ultimately become Wholly-Owned Chains?" Journal of Retailing, Pp. 44(49), 69-83. http://www.journals.elsevier. com/journal-of-retailing/

Ozanne DBA and Hunt SD. 1971. "the economics effects of franchising" select committee on small business United State Senate, Sept 81971

Perryman, Alexa A. and James G. Combs. 2012. "Who Should Own It? An Agency-Based Explanation for Multi-Outlet Ownership and Co-Location in Plural Form Franchising," Strategic Management Journal, 33 (4), 368-86. http://smj. strategicmanagement.net/ http://dx.doi.org/10.1002/smj.1947
Romano, R. E. 1994. Double moral-hazard and resale price maintenance. Rand Journal of Economics, 25, 455-466. http://www.rje.org/ http://dx.doi.org/10.2307/2555772

Rubin, P. 1978. "The Theory of the Firm and the Structure of the Franchise Contract," Journal of Law and Economics,21, Pp. 223-233. http://www.law.uchicago.edu/coase-sandor/ journals/jle http://dx.doi.org/10.1086/466918

Shane, Scott. 2005. From Ice Cream to the Internet: Using Franchising to Drive the Growth and Profits of Your Company. Upper Saddle River, NJ: Prentice Hall.

Sen, K.C. 1993. "The Use of Initial Fees and Royalties in BusinessFormat Franchising," Managerial and Decision Economics 14(2), Pp.175-190. http://onlinelibrary.wiley.com/journal/ 10.1002/(ISSN) $1099-1468$ http://dx.doi.org/10.1002/mde.4090140209

Stiglitz, J.E. 1974. "Incentives and risk-sharing in sharecropping", Review of Economics Studies, Vol. 41, Pp. 219-55. http://www.restud.com/ http://dx.doi.org/10.2307/2296714

Shelton, J.P. 1967. "Allocative Efficiency vs 'X-Efficiency': Comment," American Economic Review, LVIII, Pp.1252-1258. http://www.aeaweb.org/aer/index.php

Thomas, W.L., MJ. O'Hara, and F.W. Musgrave. 1990. "The Effects of Ownership and Investment on the Performance of Franchise Systems," American Economist,34(1), Pp. 54-61. http://www.americaneconomist.org/

Thompson D.N. 1971. Franchise Operation and antitrust, Lexington. Mass DC Heath and Co.

Thompson, R.S. 1992. "Company Ownership versus Franchising: Issues and Evidence," Journal of Economic Studies 19(4), Pp.31-42. http://www.emeraldinsight.com/products/journals/ journals.htm?id=jes http://dx.doi.org/10.1108/EUM0000000000165

Thompson, R.S. 1994. "The Franchise Life Cycle and the Penrose Effect," Journal of Economic Behavior and Organization 24(2), Pp.207-218. http://www.journals.elsevier.com/journalof-economic-behavior-and-organization/ http://dx.doi.org/10.1016/0167-2681(94)90027-2

Vaugh C L. 1974. Franchising Lexington Mass DC Heath and Co

Williamson G.1992. Franchising in Australia: The Practical Guide to All the Promises and Pitfalls. Australia: Alien \& Unwin Pty Ltd.

Williamson, Oliver E. 1996. The Mechanisms of Governance. New York: Oxford University Press.

Woll, M. 1968-69. "Sources of Revenue to the Franchisor and Their Strategic Implications." Journal of Retailing, 44(4), Pp.14-20. http://www.journals.elsevier.com/journal-of-retailing/

Zupan, Mark A. 1989. "Non-Price Concessions and the Effect of Franchising Bidding Schemes on Cable Company Costs." Applied Economics 21(3), Pp. 305-323. http://www. tandfonline.com/toc/raec20/current\#.UtxiEU0045s http://dx.doi.org/10.1080/758522549

\section{DOI: http://dx.doi.org/10.6000/1929-7092.2014.03.02}

(C) 2014 Maria Hamideh Ramjerdi; Licensee Lifescience Global.

This is an open access article licensed under the terms of the Creative Commons Attribution Non-Commercial License (http://creativecommons.org/licenses/by-nc/3.0/) which permits unrestricted, non-commercial use, distribution and reproduction in any medium, provided the work is properly cited. 